\title{
The Effect of Android Game Based Learning for Student Interest in Mathematics Learning
}

\author{
Ghany Desti Laksita*, Dewi Oktaviani, Aji Pangestu \\ Mathematics Education Department, Faculty of Mathemtics and Natural Science, Yogyakarta State University, \\ Colombo Street No.1, Daerah Istimewa Yogyakarta 55281, Indonesia. Tel.+62-274-586168, Fax. +62-274-565500. \\ Email*: ghany.laksita@gmail.com
}

\begin{abstract}
Nowadays technology is growing very rapidly. The existence of this technology development, helps a lot of people in carrying out their activities. There is one form of development technology that very influential in everyday life and mostly found in the community is an android smartphone. In this age, smartphones have become a lifestyle for the society. The development of smartphone technology has been perceived by all levels of society especially for students. Besides, being used in social media, smartphone purpose is also being used to play a game by students, both online and offline games. In the field of education, smartphones are still rarely used to support learning activities, especially in mathematics learning. This issue is happened because there are still many educators who are reluctant to switch from conventional learning methods to digital-based learning. Even though the interest of students in the smartphone technology especially game, is high enough. This research, intend to determind the effect of mathematics learning based on interactive android game to student's study interest. This research use study literature method, that is consider relevant various research, then the researcher conclude it based on the various research. The result of this research is there is an influence of learning based on interactive android game to student's interest. So, this learning based on android game can be used to increase student interest in mathematics.
\end{abstract}

Keywords: android game, learning, mathematics, student interest, study literature

\section{INTRODUCTION}

Nowadays technology is growing very rapidly. The existence of this technology development, helps people in carrying out their activities. There is one form of development technology that very influential in everyday life and mostly found in the community is an android smartphone. In this age, smartphones have become a lifestyle for the society, including Indonesian society. In fact, perceptions of smartphones are more dominant as a lifestyle, while aspects of needs and desires tend not to be too important (Chuzaimah et al. 2010). Indonesia is one of the biggest smartphone user countries in the world. According to the Digital Marketing Emarketer Research Institute estimate in 2018, the number of active smartphone users in Indonesia is more than 100 million people (Kominfo, 2019).

The development of smartphone technology has been perceived by all levels of society, especially for students. Based on survey data from Nielsen regarding the growth of the quantity of smartphone users in Indonesia from 2005 to 2010, it shows that smartphone users at the age of 15-19 years, is increased quite rapidly. Up to 2010, smartphone users aged 15-19 years ranked at the top (Figure 1).

And even in 2014 Heriyanto stated that in Indonesia $58 \%$ of the 47 million people who have smartphones are dominated by teenagers aged 14 to 17 years (Nasution et al. 2017). So that based on the data and exposure above, it can be concluded that teenagers are the most active smartphone users in Indonesia.

\section{Mobile Consumers are getting younger $\rightarrow 15-19$ yo and more recently $10-14$ yo driving the growth}

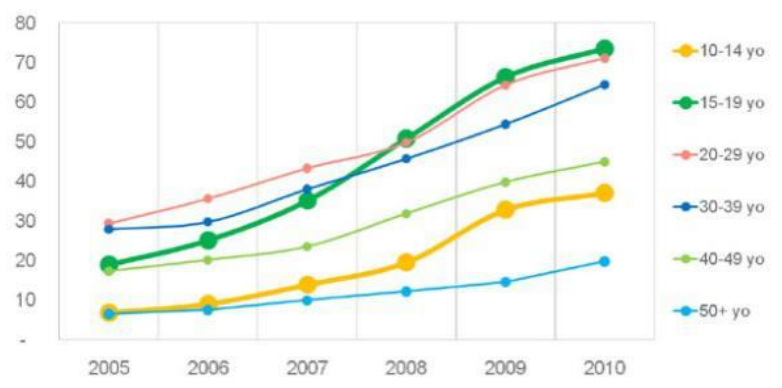

Figure 1. Nielsen survey on the growth of the quantity of smartphone users in Indonesia from 2005 to 2010.

Game is one of some application of smartphone that very popular in society, especially among teenagers. Based on the results of the Daily Social survey in 2018 in Salsabila and Setyaningrum (2019), it showed that one of the activities most often carried out by children under 18 years old on smartphones was playing games, which was $64 \%$ (Figure 2). In addition, Salsabila and Setyanignrum also stated that Indonesia is also said to be the country with the most number of downloaders of android based game applications.

Games that downloaded by teenagers are games that are merely entertaining, such as Mobile Legend. Very rarely, teens download games that related to learning. Though not a few games that have educational functions, such as the "si Cerdik" game that developed by the Indonesian Ministry of Education and Culture BPMPK. 


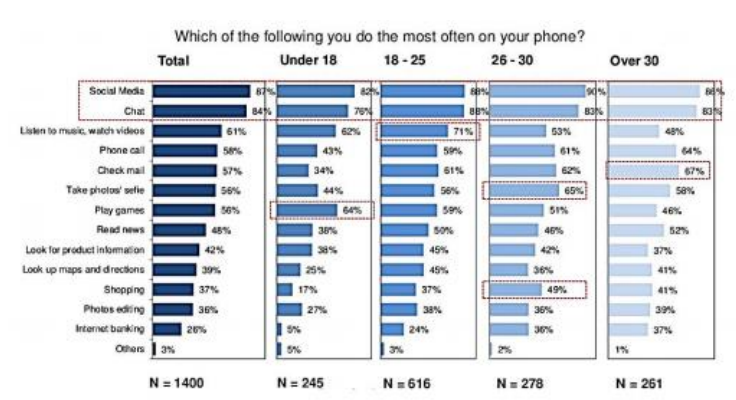

Figure 2. Daily social survey on the use of smarthpone in Indonesia in 2016.

According to the Law of the Republic of Indonesia Number 2 on 1989 Concerning the National Education System, education is a conscious effort to prepare students through guidance, teaching and/or training activities for their role in the future. So here it is very clear that education is very important for teenager because it plays a role for their future. Because of the important role of education, learning needs to be done effectively. With effective learning, the objective of learning can be achieved, so that education can be said to be successful. Effective learning methods that is if learning is not focused on the results achieved by students only, but how an effective learning process is able to provide understanding. To understand a concept, of course student interest in learning plays an important role in learning. With the technology and student interest in games, educational game-based learning might be a solution in improving the quality of learning.

Mathematics lessons are still considered as boring learning. This is due to there are still many educators who teach with conventional methods. This method does not attract the interest of student in learning, so their interest in learning mathematics tends to be low. In order for students to be interested in learning, it is necessary to hold learning innovations so that they can change paradigm of student towards mathematics learning, which was originally boring learning into fun learning that can attract students' learning interests.

Based on the explanation above, it is suspected that there is an influence between mathematics learning with educational game media on smartphone with student interest in learning.

\section{MATERIALS AND METHODS}

\section{Materials \\ a. Mathematics Learning}

According to the Law of the Republic of Indonesia Number 20 on 2003 Concerning the National Education System paragraph 1 verse 20 stated that learning is a process interaction of students with educators and learning resources in a learning environment. From the opinion above, learning can be used as an aid from educators to students, so that the process of acquiring knowledge, forming attitudes and beliefs and having good skills can be built. In other words, learning can be interpreted as an effort to help students in order to get a good learning process. Therefore, in arranging learning, educators need to create an effective learning atmosphere and fun learning strategies to attract students interest to learn. Effective learning is very dependent on innovation in preparing the learning flow and learning motivation. Learning targets can be measured through changes in attitudes, changes in abilities and skills of students in the learning process. The learning process is done for a person's entire life and can be done wherever and whenever.

Learning related to subjects. One subject that must be studied by students is Mathematics. In Government Regulation number 26 on 2016 concerning content standards, mathematics is a science that has the aim to recognize, respond to, and appreciate science and technology and instill critical, creative and independent thinking (Aji et al, 2019). In the same hand with this opinion, according to Erman Suherman (2003, p.16) explained that mathematics is formed as a result of human thought related to ideas, processes, and reasoning. Besides that, mathematics is a pattern of thinking, coordinating patterns, logical proof, using terms that are defined carefully, clearly, and accurately. Its presentation with symbols and solid, more in the form of symbolic language about ideas. So from these definitions, it can be concluded that mathematics is a collection of abstract ideas from the results of critical thinking and logic, to recognize, respond and appreciate science and technology.

\section{b. Educational Game}

Game comes from the English language means game. According to Costikyan (2013, p.20), a game is a work of art that engages players to make decisions to manage the game. Meanwhile, according to Samuel Henry, games are an inseparable part of children's daily lives. In connection with the opinion of Samuel Henry, Joan Freeman and Utami Munandar defines the game as an activity that helps children achieve development, both physical, intellectual, social, moral and emotional. Based on the description above, it can be concluded that the game is a digital and non-digital game that involves the player in making a decision to solve the problem so that the game's goal is achieved. With that, it can help the player (student) to develop their physical, intellectual, social and emotional.

The word education comes from English, namely education which means education. According UU No. 2 on 1989, education is a conscious effort to prepare students through guidance, teaching and training activities for their roles in the future. The opinion of the purpose of education is to develop students' potentials to be the good of future generations.

According to Handriyantini (2019) defines that educational games as one of the learning media with the 
aim of stimulating students' thinking and concentration through unique and interesting media. Based on the description, the game is not only used in terms of entertainment, but can also be used as a learning tool in order to produce effective learning. This type of game, invites players (students) to learn while playing. With the concept of a game, that applies the goal as a determinant of a player's win or lose, the game certainly presents problems that must be solved first before reaching the goal. With the existing problems, students feel challenged to play and learning. Educational game based learning lies in the problems that can develop students' cognitive. Because educational games are intended for students to be able to increase students' interest in learning, so the game itself must be interesting and innovative.

\section{c. Interest to Learn}

According to Simbolon (2013) interest can be interpreted to be interested or encouraged to pay attention to someone's goods or activities in certain fields. According to Slameto $(2010$, p.57) in Siaga (2012) interest is a constant tendency to pay attention constantly and remember some activities.

According to Astuti (2015) interest in learning is a feeling of pleasure, love and attention to business for get knowledge. According to Lestari (2013) interest in learning is an inner urge that grows from a student to improve learning habits. According to Siagian (2012), interest in learning mathematics is a feeling of pleasure towards mathematics lessons where a student pays great attention to mathematics and makes mathematics an easy subject.

Interest according to Djamarah (2011,p.167) there are several kinds of ways that can be done by teachers to arouse student interest, that is, (1) compare the existence of a need in students themselves, so he is willing to learn without coercion; (2) relate learning material provided with the problem of the experience that students have, so that students easily receive learning material; (3) provide opportunities for students to get good learning outcomes by providing a creative and conducive learning environment; (4) use various forms and teaching techniques in the context of individual differences of students (Simbolon, 2013).

\section{Methods}

This research is conducted using literature study method, which is looking for references needed for research. The reference that needed in this research is reference that related to the effect of android game based learning on increasing interest of student in learning mathematics. After reviewing the references, the researcher concludes based on the results obtained.

According to Taylor, the process of selecting literature was carried out with four procedures, that is (1) organize, organize literature that will be reviewed. The literature reviewed is relevant / in line with the problem.
The stage in organizing literature is to look for ideas, general objectives, and conclusions from the literature by reading abstracts, introductory paragraphs, and conclusions, and classifying the literature based on certain categories; (2) synthesize, which unites the results of the organization of literature into a summary in order to become a unified unity, by looking for links between literatures; (3) identify, videlicet identifies issues of controversy in the literature. The issue of controversy in this case is an issue that is considered very important to peel or analyze, in order to get an interesting writing to read; and (4) formulate, namely formulating questions that require further research. (Pangestu et al. 2019)

\section{RESULTS AND DISCUSSION}

Smartphone technology is developing rapidly both in terms of features and software. In terms of software, there are many applications developed with android platform that can be used by users. One type of android application that is very popular in society, especially among students, is gaming. Games can be developed further from just games that are merely for entertaining into educational entertaining games.

Games are both digital and non-digital games that involve players in making decisions to solve problems so that the game's goals are achieved. According to Handriyantini (2019) defines educational games as one of the learning media with the intention to stimulating students' thinking and concentration through unique and interesting media. With this educational game, can develop the physical, intellectual, social and emotional abilities of students. Educational game based learning lies in the problems in the game that can develop cognitive of students. So that in addition to creating interesting and fun learning, this game-based learning can also create effective learning.

Learning must be done effectively so that learning objectives can be achieved. One sign that learning is effective learning is that when lessons take place, students can pay full attention to learning. So that students can pay full attention it is necessary to have an interest in learning from students themselves. Interest is the tendency or interest of someone towards something, so that it influences that person to pay attention to something earlier. Then, if students have an interest in learning, students will make more effort to pay attention to the lesson.

Interest according to Djamarah (2011,p.167) there are several kinds of ways that can be done by teachers to arouse student interest, that is, (1) compare the existence of a need in students themselves, so he is willing to learn without coercion; (2) relate learning material provided with the problem of the experience that students have, so that students easily receive learning material; (3) provide opportunities for students to get good learning outcomes 
by providing a creative and conducive learning environment; (4) use various forms and teaching techniques in the context of individual differences of students (Simbolon, 2013). Furthermore, Simbolon (2013) states, relating to the opinions above teachers need to arouse students' interest in learning so they can be excited to receive lessons, make students aware of being directly involved in learning, learn with fun and can use a variety of methods, strategies, techniques and approaches to learning that are fun.

Based on the explanation above, one of the ways that can be done by the teacher to arouse students' interest is by using various forms and teaching techniques by taking a learning approach that can attract the interest of students by educational games. Educational game based learning can attract attention of students and can make students as active parties in learning.

Educational game well applied in mathematics because it can support student interest towards mathematics. In the mathematics game, problems are given which the students must solve in order to achieve the goal of the game. Students will feel challenged to solve these problems and motivated to learn because the games is fun, creative and interesting. This educational games, can make students to focus and concentrate on learning mathematics. So in that way, learning will be more easily absorbed by students. This is consistent with the purpose of making educational games by Handriyantini (2019), which educational game is one of the media that can stimulate thought and concentration of students through a unique and exciting media. This is also in accordance with the success factors of a good learning that can be seen from the level of student attention. More interesting the educational $g$ more the students' interest in learning and the level of student interest in learning mathematics can be increase.

In addition, educational games for learning media can also increase student 's activity in learning, both directly and indirectly. A good game will include interaction with players. In addition to interacting with media educational games, students can also discuss with their classmates and can ask the teachers. Having these experiences in educational game, makes the students not only learn but also participate in learning. This experience also triggers the students to be motivated to learn. So that the goal of learning can be achieved, there are the process of interaction between students and educators and learning resources in a learning environment.

\section{CONCLUSION}

Educational game has an influence on students' interest in learning mathematics. This can be seen by the attention, active participation and experience of new experiences from this educational games that can influence student interest in learning. If the educational game is packaged in a fun, creative and easy to understand form, then students' interest in learning through educational games will also certainly increase.

\section{REFERENCES}

Astuti, Siwi Puji. 2015. Pengaruh Kemampuan Awal dan Minat Belajar terhadap Prestasi Belajar Fisika. FORMATIF: Jurnal Ilmiah Pendidikan MIPA. Volume 5, Number 1.

Chuzaimah, et al. 2010. Smartphone: Antara kebutuhan dan Elifestyle. Proceeding of Seminar Nasional Informatika 2010 (semnasIF 2010). Volume 1.

Kominfo. 2019. Indonesia Raksasa Teknologi Digital Asia. www.kominfo.go.id

Lestari, Indah. 2013. Pengaruh Waktu Belajar dan Minat Belajar terhadap Hasil Belajar Matematika. FORMATIF: Jurnal Ilmiah Pendidikan MIPA. Volume 3, Number 2.

Nasution JA, et al. 2014. Motif Siswa Memiliki Smartphone dan Penggunaannya. JPPI (Jurnal Penelitian Pendidikan Indonesia). Volume 3 Number 2: 15-29.

Nielsen. 2011. Mobile Phone Penetration in Indonesia Triples in Five Years. www.nielsen.com

Pangestu A, et al. 2019. Pemanfaatan Media Pembelajaran Berbasis Augmented Reality (AR) pada Minat Belajar Matematika Siswa. Proceeding of Sendika. Volume 5, Number 1.

Putra, Made Jaya Ardi. 2016. Rancang Bangun Game Edukasi Wisata dan Budaya Bali, Skripsi. Bali: Udayana University.

Salsabila NH, Setyaningrum W. 2019. Pengembangan Media Pembelajaran Matematika Berbasis Game: Statistics in Arctic. MANDALIKA Mathematics and Educations Journal Volume 1 Nomor 1.

Sari, Novita Ida. 2015. Rancang Bangun Aplikasi Game Edukasi Pakaian Adat Suku Batak "Ulos" pada Platform Android, Skripsi. Bali: Udayana University.

Siagian, Roida Eva Flora. 2012. Pengaruh Minat dan Kebiasaan Belajar Siswa terhadap Prestasi Belajar Matematika. FORMATIF: Jurnal Ilmiah Pendidikan MIPA. Volume 2, Number 2.

Simbolon, Naeklan. 2013. Faktor-Faktor yang Mempengaruhi Minat Belajar Peserta Didik. Elementary School Journal PGSD FIP UNIMED. Volume 1, Number 2.

Vitianingsih, Anik Vega. 2016. Game Edukasi Sebagai Media PEmbelajaran Pendidikan Anak Usia Dini. Journal of INFORM. Volume 1, Number 1. 